\title{
Forests and climate change - lessons from insects
}

\begin{abstract}
Battisti A*
Abstract: The climate change may indirectly affects the forest ecosystems through the activity of phytophagous insects. The climate change has been claimed to be responsible of the range expansion northward and upward of several insect species of northern temperate forests, as well as of changes in the seasonal phenology. Several papers have dealt with the prediction of the most likely consequences of the climate change on the phytophagous insects, including some of the most important forest pests. Increased levels of $\mathrm{CO}_{2}$ in the atmosphere involve an increase of the $\mathrm{C} / \mathrm{N}$ balance of the plant tissues, which in turn results in a lower food quality for many defoliating insects. Some insects respond by increasing the level of leaf consumption and consequently the damage to the tree, whereas others show higher mortality and lower performance. The level of plant chemical defences may also be affected by a change of $\mathrm{CO}_{2}$. The temperature is affecting either the survival of the insects which are active during the cold period, such as the pine processionary moth, or the synchronization mechanism between the host and the herbivores, as in the case of the larch bud moth. An increase of temperature may alter the mechanism by which the insects adjust their cycles to the local climate (diapause), resulting in faster development and higher feeding rate, as in the case of the spruce web-spinning sawfly outbreaks in the Southern Alps.
\end{abstract}

Keywords: temperature, phenology, range, host-insect relationships

\section{Climate change and insect distribution}

The effects of global warming on living organisms have now been recognized from the level of individual species to communities, most notably in the form of temperature-related range shifts (Walther et al. 2002, Root et al. 2003, Hickling et al. 2006). As the number of insects per unit area is inversely related to latitude and elevation (Speight et al. 1999), we may assume that the increase of temperature would allow the spreading of insect species northward and upward, especially for those species that have wide ranges, as many forest pests have. This assumption is supported by fossil data related to the forest insect response to climatic changes of the past. Higher damage and insect diversity was recorded during the global warming which occurred during the Paleocene - Eocene transition, relative to other periods (Wilf \& Labandeira 1999).

With mean global temperatures increasing over the past 100 years by about $0.8^{\circ} \mathrm{C}$ and

* Dipartimento Agronomia Ambientale e Produzioni Vegetali, Università di Padova, Via Università 16, Agripolis, 35020 Legnaro (PD), Italy

\section{Email: Andrea Battisti}

(andrea.battisti@unipd.it).

Citation: Battisti A, 2008. Forests and climate change - lessons from insects. iForest 1: 1-5 [online: Feb 28, 2008] URL: http://www.sisef.it/iforest/ projected to continue (Solomon et al. 2007), widespread climate-related changes in the biosphere can be expected. There are various ways by which the insects may react to climate change (Williams \& Liebhold 1995, Ayres \& Lombardero 2000, Harrington et al. 2001, Bale et al. 2002, Parmesan 2006), and it seems reasonable to assume that an increase of temperature within the vital limits of a species implies a faster development. The species ready to expand are those characterized by high growth potential, multivoltinism and absence of diapause, whereas those that could be restricted show slow development rate and long cycles. The reduction of the period of time spent as a larva or pupa may improve survival, as these are the stages more subjected to predation and other mortality factors (Bernays 1997). The increase in population density may in turn promote a further expansion of the range. Some species would be simply limited in their survival at the southern edge of their range and would shift the range northward. Switching to new hosts may occur among non-specialist herbivores, and can be the first consequence of the strong selection on colonizers (Harrington et al. 2001, Stastny et al. 2006).

Parmesan \& Yohe (2003) have provided a quantitative assessment of the biological impact of climatic change, using data from different types of organisms, including insects. This analysis concerned the spatial (range shift) and phenological (advancement of spring events) data, averaging $6.1 \mathrm{~km} /$ decade and 2.3 days/decade, respectively. Eighty percent of the studied species $(n=434)$ showed a consistent range shift and $87 \%$ an advancement of spring events, such as flowering or migration.

However, the response of insects to climatic change may not always be linear (Bale et al. 2002, Gaston 2003). For example, the developmental stages of the insects can be differentially affected by the climate change, i.e. the growth can be accelerated by higher temperature, but at the same time the length of diapause may be extended.

Those insects developing without winter diapause, which are active during this season and are protected from the low temperature, are the best candidates for range expansion if the winter temperature maintain the current increasing trend (Sinclair et al. 2003). The increase in winter temperature is a key factor for the survival of the lepidopteran Atalopedes campestris in the new colonization areas (Crozier 2004). A good example concerning a forest pest is the case of the pine processionary moth Thaumetopoea pityocampa (Box 1, Fig. 1), reported also in the last IPCC report (Rosenzweig et al. 2007).

However, most forest insects of temperate regions have a winter diapause, which in some cases can last several years. Temperature plays a major role in the induction and maintenance of this diapause. An increase of the temperature would modify the induction and maintenance of the diapause, involving changes, which could affect the development of the insect, making predictions about population dynamics quite unreliable. Two examples are reported here, which illustrate how high temperature during the larval development has caused lower diapause rate and higher damage by the spruce webspinning sawfly Cephalcia arvensis (Box 2), and how high winter temperature has disrupted the maintenance and termination of the egg diapause in the larch bud moth Zeiraphera diniana (Box 3), causing a poor synchronization with the host and the absence of an expected outbreak.

A different situation is presented by species that are already adapted to the cold environments, such as Aglais urticae. These would probably undergo a restriction of the range if they become limited at their southern boundary by increasing temperature (Bryant et al. 1997).

For insects that are heavily dependent on a favourable synchronization between bud breaking and hatching, such as the winter moth Operophtera brumata, it appears that there may be a compensation between a faster egg spring development and a delayed pupation in autumn, both triggered by an in- 


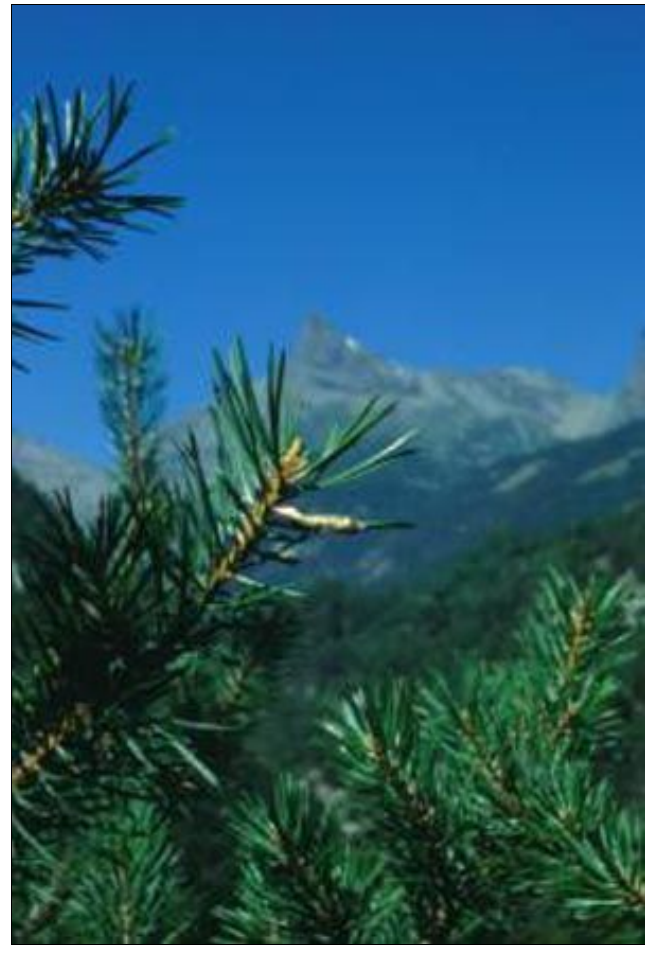

Fig. 1 - Egg batch of the pine processionary moth Thaumetopoea pityocampa on a twig of Pinus sylvestris in the expansion outbreak area of Mont Avic (Aosta), at the unusual elevation for an alpine population of $1450 \mathrm{~m}$. The insect shows high performance and almost no mortality due to the absence of the main natural enemies; a genetic analysis has shown that the population originated from different sources, suggesting that female moths are flying over bigger distances than previously believed (Salvato et al. 2002).

crease of temperature (Buse \& Good, 1996). Therefore, phenology is not affected, allowing Bale et al. (2002) to conclude that the effects of the global warming would not be so evident in some species.

Finally, the natural enemies of forest insects may be affected by the temperature change in different directions or extent. The expansion of the host may not be promptly followed by that of its enemies, as in the case of the pine processionary moth (Zovi et al. in press), or the synchronization between

host and parasitoid may not be maintained under new temperature conditions. This seems to be the case of a parasitoid of the winter moth Operophtera brumata, which is effective at low elevation but that is almost absent at high elevation (Kerslake et al. 1996).

All the examples cited above illustrate how insects may react to the climate change, however they also have a great potential to develop physiological and behavioural adaptations, which may improve their fitness

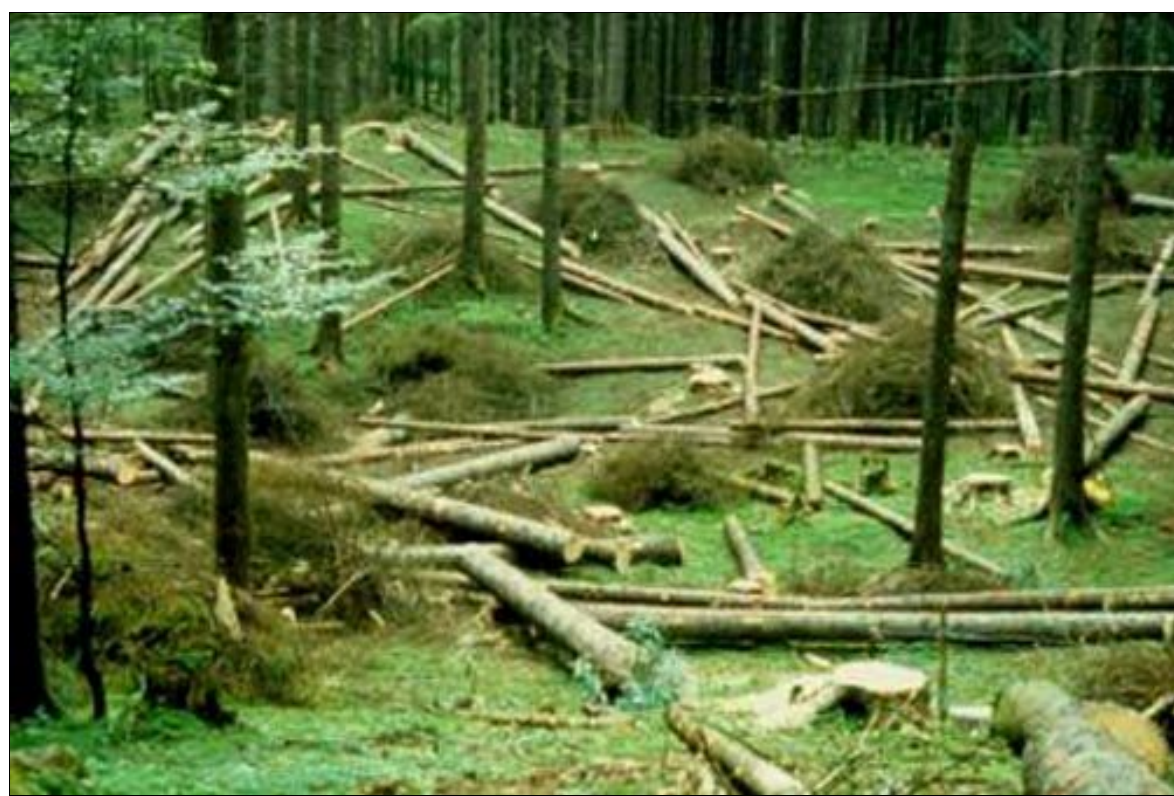

Fig. 2 - Salvation logging after repeated defoliation of the spruce web-spinning sawfly Cephalcia arvensis in Norway spruce stands of Cansiglio Plateau (Southern Alps). This was the first outbreak of this insect ever recorded in the Alps, where it is endemic.
Box 1 - The pine processionary moth Thaumetopoea pityocampa

The winter pine processionary moth, Thaumetopoea pityocampa offers a possibility to test for the effects of global warming on an insect population over a wide area of the Mediterranean basin and southern parts of Europe, where it is the most important pest of pine forests (Pinus spp.). Its geographic range lies within precise limits of elevation and latitude (Démolin 1969), primarily as a function of the average winter temperatures. Because the larvae are oligophagous, potentially feeding on all Pinus spp., but also on Cedrus spp. and the introduced Pseudotsuga menziesii, host plant distribution does not restrict the present range of the insect; many usual or potential host species grow in areas where the insect is absent. Consequently, if the climatic conditions become favourable in higher latitudes or at higher elevations, the insect may expand its range to these areas, often coupled with host switching (Battisti et al. 2005, Robinet et al. 2007). This relative importance of temperature over biotic factors in defining the geographic distribution makes the moth a particularly suitable model to study the range shift in relation to global warming (Buffo et al. 2007).

An important forest pest in many areas, the moth has shown in the last decades a substantial expansion of the outbreak area both northward and upward (Huchon \& Démolin 1971, Hodar et al. 2003, Battisti et al. 2005), aggravated by extreme climatic events such as the summer of 2003 (Battisti et al. 2006). This has resulted in high attack rates in areas previously largely unaffected by the insect (Stastny et al. 2006). The case deserves special interest for the implications it may have on the management of European forests and plantations, as well as on ornamental trees.

under new conditions. This would ultimately lead to the formation of genetically differentiated populations and possibly new species, especially when the climatic change is associated with range expansion and host switch.

\section{Climate change and host-insect \\ interactions}

The capacity of an herbivore insect to complete its development depends on the adaptation to both, the environmental conditions and the host plant. The plant may respond to changes in temperature by varying its growth 


\section{Box 2 - The spruce webspinning sawfly Cephalcia arvensis}

The outbreaks of the spruce web-spinning sawfly Cephalcia arvensis in the Southern Alps are a good example of what may happen when favourable climatic conditions interfere with the mechanism of the induction of extended diapause, allowing an exponential growth of the population and consequent damage to trees. This species, as many others in this genus, is monophagous on Picea and endemic to the spruce range in Eurasia, where outbreaks have been seldom recorded (Marchisio et al. 1994). Cephalcia species generally show low fecundity and spreading of the cohort over many years by mean of an extended diapause, which is induced by low temperature at pupation time (Battisti 1994). However, in the period 1985-1992 there was a sudden outbreak in the Southern Alps (Asiago and Cansiglio Plateaux - Fig. 2), during which the populations developed an annual life cycle and grew exponentially, causing repeated defoliations, which ultimately caused tree death over hundreds of hectares (Battisti et al. 2000). The most likely reasons for such a change in the life cycle of the insect have been explored through an analysis of the local climate, which showed that the years preceding the outbreak were characterized by an abnormally warm and dry weather during the feeding period of the larvae. We hypothesized that favourable conditions promoted the survival and speeded up the development, making it possible to pupate when soil temperature was high enough to start pupation immediately, skipping in this way from the extended diapause. Later, an experiment showed that the soil threshold temperature for the induction of the extended diapause was about $12^{\circ} \mathrm{C}$ (Battisti 1994), well below the values recorded in the forest at the beginning of the outbreak. The sudden increase of the population density was not quickly followed by that of natural enemies, which were unable to limit population growth (Battisti et al. 2000). It seems likely that the increase of the temperature in June and July of 1983-85 is the major factor promoting the outbreaks, as they occurred simultaneously at two sites at a distance of about $100 \mathrm{~km}$, through switching the insects to an annual generation.

rate, as it is commonly observed along latitudinal or altitudinal gradients, when the conditions become progressively less favorable and the herbivores are more limited in the host's exploitation. An example is given by the willow psyllid (Cacopsylla spp.), which is restricted to feed on a low number of species or types of plant tissues as the range edge is approached (Hodkinson 1997, Hill et al. 1998).

The change of temperature, which promotes the expansion of the insect's range, may also involve a new association between a herbivore and its host, as it has been shown by the pine processionary moth attacking the mountain pine (Pinus mugo) in the southern Alps. The large outbreaks observed in the expansion areas on the new hosts may be explained either by the high susceptibility of the hosts or by the inability of natural enemies to locate the moth larvae on an unusual hosts or environment (Hodar et al. 2003, Stastny et al. 2006).

An elevated concentration of $\mathrm{CO}_{2}$ may affect the performance of phytophagous insects through the modification of the nutritional properties of the host plant (Jones et al. 1998, Hunter 2001, Knepp et al. 2005). As $\mathrm{CO}_{2}$ is the main carbon source for photosynthesis, its increase could alter the carbon/nutrient balance of plants, increasing the $\mathrm{C} / \mathrm{N}$ ratio and thus diluting the nitrogen content of the tissues. However, the response of plants to increased $\mathrm{CO}_{2}$ varies among species. A high concentration causes an increase of tannins in the leaves of birch, poplar and maple, but not in the eastern white pine (Pinus strobus) (Roth \& Lindroth 1994).

The first reaction expected from herbivores to the increase of the $\mathrm{C} / \mathrm{N}$ ratio is compensatory feeding, in other words they should eat more to accumulate enough nitrogen for their development. Thus, plant damage may increase, but plant biomass could remain stable if we assume that the plants exposed to high $\mathrm{CO}_{2}$ grow more. Phytophagous insects may also develop adaptations to overcome higher $\mathrm{C} / \mathrm{N}$ ratios, such as the pine sawfly Neodiprion lecontei, which shows an increase in the efficiency of nitrogen utilization when reared on plants treated with high $\mathrm{CO}_{2}$ concentration (Williams et al. 1994). However, other insect species seem unable to compensate the lower nutritional quality of the plants by increasing the efficiency of nutrient utilization (Brooks \& Whittaker 1999, Stiling et al. 1999). The experiments of Lindroth et al. (1993), on three species of saturnid moths, show that the performance of the caterpillars is only marginally affected when the nitrogen content of the leaves is reduced by $23 \%$ and the $\mathrm{C} / \mathrm{N}$ ratio increased by $13-28 \%$.

Experiments combining different concentrations of both nitrogen and carbon dioxide supplied to Norway spruce showed that a high nitrogen level may compensate the effects of $\mathrm{CO}_{2}$ on the concentration of nutrients and defence compounds in the shoots, limiting the negative effects on the test insect Lymantria monacha (Haettenschwiler \& Schafellner 1999).

The effects of a modified atmosphere on herbivore insects could also involve the third trophic level, i.e. their parasitoids and predators. As we are expecting a delay in the developmental time of the herbivores after exposure to high $\mathrm{CO}_{2}$ (Fajer et al. 1989, Lindroth et al. 1993, Smith \& Jones 1998), the probability of parasitism and predation should increase as well. Experimental evidence of such a hypothesis is contradictory, as

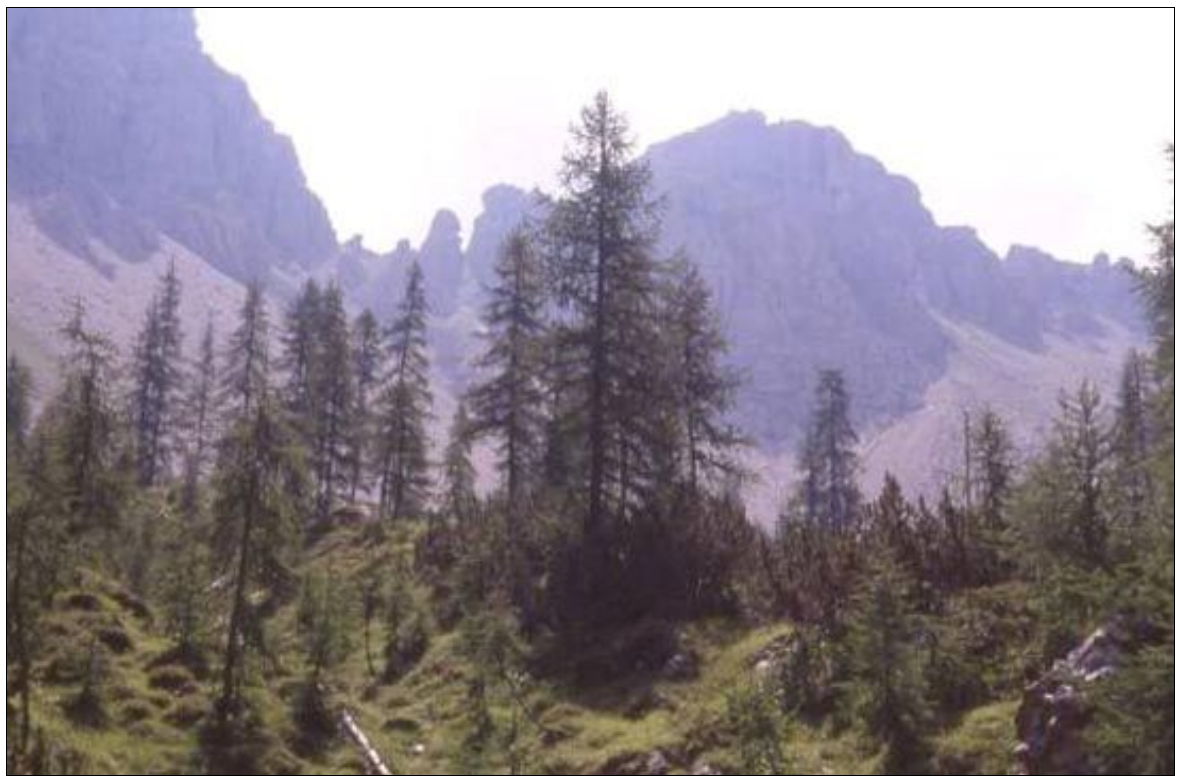

Fig. 3 - Larch stand at timberline in the Eastern Dolomites, where the cyclic outbreaks of the larch bud moth Zeiraphera diniana are less regular and of variable intensity, fitting the model of the easterly directional population waves created by Bjornstad et al. (2002), based on the 35-year dataset of Baltensweiler \& Rubli (1999). 
Roth \& Lindroth (1995) did not find highe parasitism by the hymenopteran Cotesia melanoscela on the larvae of Lymantria dis par raised at high $\mathrm{CO}_{2}$, whereas Stiling et al. (1999) found higher mortality of oak leaf miners by parasitoids on two species of oak (Quercus myrtifolia, Q. geminata) grown at high $\mathrm{CO}_{2}$ level.

Laboratory or greenhouse experiments provide valuable data, but it is difficult to de-

\section{Box 3 - The larch bud moth Zeiraphera diniana}

The larch bud moth Zeiraphera diniana is likely the best example of a forest insect showing population cycles in Europe, where it has been defoliating large patches of larch stands in the Alps every 8-10 years for centuries (Baltensweiler \& Rubli 1999). This insect has an annual life cycle and spends the winter as an egg on the larch branches, starting to feed on the needles as soon as the bud breaks. Multiple factors seem to be involved in triggering the cycles, such as the host plant quality, the natural enemies, and the migration of the moths (Baltensweiler \& Rubli 1999, Bjornstad et al. 2002, Turchin et al. 2003). However, a disturbance probably related to climate change has caused the collapse of an outbreak, which was started in 1989 in the traditional occurrence area in Upper Engadine Valley (Baltensweiler 1993). In the following years the larval density decreased drastically and Baltensweiler (1993) was able to demonstrate that it was due to unusually high egg mortality, caused by repeated unfavourable weather conditions in winter and spring 1989-91. In fact, it appears that weather is a critical factor for a good synchronization between bud burst and hatching of the larvae. Since these conditions occurred in three successive generations, population growth was effectively reduced and the cycle collapsed prematurely. In a recent analysis of European temperature trend since 1500 (Luterbacher et al. 2004), it appears that "the winter $1989 / 1990\left(\Delta \mathrm{T}=+2.4^{\circ} \mathrm{C}\right)$ and the decade 1989 to $1998\left(\Delta \mathrm{T}=+1.2^{\circ} \mathrm{C}\right)$ were the warmest since 1500 . The period 1989 to 1998 was almost two standard errors warmer than the second warmest (non-overlapping) decade (1733 to 1742, $\left.\Delta \mathrm{T}=+0.45^{\circ} \mathrm{C}\right)$, thus was very likely $(95 \%$ confidence level) warmer than any other decade since 1500". The abnormally high temperature recorded in that period is possibly the reason for the disruption of the coincidence between the larch and the bud moth, probably through the induction of high egg mortality. rive conclusions applicable to the natural environment. For example, high $\mathrm{CO}_{2}$ levels are known to increase the temperature and, indirectly may affect the host-herbivore interaction.

Dury et al. (1998) showed that an increase of $3^{\circ} \mathrm{C}$ of the temperature might lead to the same effects of an increase of $\mathrm{CO}_{2}$ (decrease of nitrogen, increased of condensed tannins) on oak leaves. However, an increase of temperature may enhance the feeding of the herbivore and thus compensate for the negative effects of a lower food quality. An experiment that tested simultaneously the effects of different levels of $\mathrm{CO}_{2}$, nitrogen and temperature on the monoterpene production of Pseudotsuga menziesii (Litvak et al. 2002), indicated that the synthesis of these defence compounds was more affected by individual tree variability than by the treatments.

The response of herbivore insects to increased $\mathrm{CO}_{2}$ may also differ among the feeding guilds, as suggested by Bezemer \& Jones (1998). Defoliators are generally expected to increase leaf consumption by about $30 \%$, but leaf miners showed a much lower rate. Phloem-sucking insects appear to take the greatest advantage from increased $\mathrm{CO}_{2}$, as they grow bigger and in a shorter time. In a FACE (Free Air Carbon Enrichment) experiment carried out in Wisconsin (Percy et al. 2002), the activity of all guilds of herbivores, combined with the effect of increased ozone, may be compensated by the beneficial consequences of enriched $\mathrm{CO}_{2}$ on growth of Populus tremuloides.

More research is clearly needed to make reliable predictions about the effects of climate change on the relationships between the forest trees and phytophagous insects. Good conceptual frameworks, such as the carbon/nutrient balance (Bryant et al. 1983) and the growth/differentiation balance (Herms \& Mattson 1992) theories are available to interpret experimental results and to formulate new hypotheses. Hopefully, this understanding of the effects of climate change on forest pests will enable us to take the necessary measures to counteract or mitigate the possible negative consequences on the forest ecosystems.

\section{Acknowledgements}

This work has been supported by the EU $5^{\text {th }}$ FP QLK5-CT-2002-00852 project "Promoth" (Global change and pine processionary moth: a new challenge for integrated pest management) and by the project "Forest Monitoring" of Regione del Veneto. I thank Michael Stastny and Edoardo Petrucco Toffolo for the useful discussions and for the help in screening the literature.

\section{References}

Ayres MP, Lombardero MJ (2000). Assessing the consequences of global change for forest disturb- ance from herbivores and pathogens. Science of the Total Environment 262: 263-286.

Bale JS, Masters GJ, Hodkinson ID, Awmack C, Bezemer TM, Brown VK, Butterfield J, Coulson JC, Farrar J, Good JG, Harrington R, Hartley SE, Jones TH, Lindroth RL, Press MC, Syrmnioudis I, Watt AD, Whittaker JB (2002). Herbivory in global climate change research: direct effects of rising temperature on insect herbivores. Global Change Biology 8: 1-16.

Baltensweiler W (1993). Why the larch bud-moth cycle collapsed in the subalpine larch-cembran pine forests in the year 1990 for the first time since 1850. Oecologia 94: 62-66.

Baltensweiler W, Rubli D (1999). Dispersal: an important driving force of the cyclic population dynamics of the larch bud moth, Zeiraphera diniana Gn. Forest Snow and Landscape Research 74: 1-153.

Battisti A (1994). Voltinism and diapause in the spruce web-spinning sawfly Cephalcia arvensis. Entomologia experimentalis et applicata 70: 105113.

Battisti A, Boato A, Masutti L (2000). Influence of silvicultural practices and population genetics on management of the spruce sawfly, Cephalcia arvensis. Forest Ecology and Management 128: 159-166.

Battisti A, Stastny M, Netherer S, RobinetC, Schopf A, Roques A, Larsson S (2005). Expansion of geographic range in the pine processionary moth caused by increased winter temperatures. Ecological Applications 15: 2084-2096.

Battisti A, Stastny M, Buffo E, Larsson S (2006). A rapid altitudinal range expansion in the pine processionary moth produced by the 2003 climatic anomaly. Global Change Biology 12: 662671.

Bernays EA (1997). Feeding by lepidopteran larvae is dangerous. Ecological Entomology 22: 121-123.

Bezemer TM, Jones TH (1998). Plant-insect herbivore interactions in elevated atmospheric $\mathrm{CO}_{2}$ : quantitative analyses and guild effects. Oikos 82 : 212-222.

Bjørnstad ON, Peltonen M, Liebhold AM, Baltensweiler W (2002). Waves of larch budmoth outbreaks in the European Alps. Science 298: 1020-1023.

Brooks GL, Whittaker JB (1999). Responses of three generations of a xylem-feeding insect, $\mathrm{NeO}$ philaenus lineatus (Homoptera), to elevated $\mathrm{CO}_{2}$. Global Change Biology 5: 395-401.

Bryant JP, Chapin FS III, Klein DR (1983). Carbon/nutrient balance of boreal plants in relation to vertebrate herbivory. Oikos 40: 357-368.

Buffo E, Battisti A, Stastny M, Larsson S (2007). Temperature as a predictor of survival of the pine processionary moth in the Italian Alps. Agricultural and Forest Entomology 9: 65-72.

Buse A, Good JEG (1996). Synchronization of larval emergence in winter moth (Operophtera brumata L.) and budburst in pedunculate oak (Quercus robur L.) under simulated climate change. Ecological Entomology 21: 335-343.

Crozier L (2004). Warmer winters drive butterfly 
range expansion by increasing survivorship. Ecology 85: 231-241.

Démolin G (1969). Bioecologia de la procesionaria del pino Thaumetopoea pityocampa Schiff. Incidencia de los factores climaticos. Boletin Servicio Plagas Forestales 12: 9-24.

Dury SJ, Good JEG, Perrins CM, Buse A, Kaye T (1998). The effects of increasing $\mathrm{CO}_{2}$ and temperature on oak leaf palatability and the implications for herbivorous insects. Global Change Biology 4: 55-61.

Fajer EP, Bowers MD, Bazzaz FA (1989). The effects of enriched carbon dioxide atmospheres on plant-insect herbivore interactions. Science 243: 1198-1200.

Gaston KJ (2003). The Structure and Dynamics of Geographic Ranges. Oxford University Press, New York, US.

Haettenschwiler S, Schafellner C (1999). Opposing effects of elevated $\mathrm{CO}_{2}$ and $\mathrm{N}$ deposition on Lymantria monacha larvae feeding on spruce trees. Oecologia 118: 210-217.

Harrington R, Fleming RA, Woiwod IP (2001). Climate change impacts on insect management and conservation in temperate regions: can they be predicted? Agricultural and Forest Entomology 3: 233-240.

Herms DA, Mattson WJ (1992). The dilemma of plants: to grow or defend. The Quarterly Review of Biology 67: 283-313.

Hickling R, Roy BR, Hill JK, Fox R, Thomas CT (2006). The distributions of a wide range of taxonomic groups are expanding polewards. Global Change Biology 12: 450-455.

Hodar JA, Castro J, Zamora R (2003). Pine processionary caterpillar Thaumetopoea pityocampa as a new threat for relict Mediterranean Scots pine forests under climatic warming. Biological Conservation 110: $123-129$.

Houghton JT, Ding Y, Griggs DJ, Noguer M, van der Linden PJ, Xiaosu D, Maskell K, Johnson CA (2001). Climate Change 2001: The Scientific Basis. Cambridge University Press, Cambridge, UK.

Huchon H, Démolin G (1971). La bioécologie de la processionaire du pin. Dispersion potentielle. Dispersion actuelle. Phytoma 225: 11-20.

Hunter MD (2001). Effects of elevated atmospheric carbon dioxide on insect-plant interactions. Agricultural and Forest Entomology 3: 153-159.

Knepp RG, Hamilton JG, Mohan JE, Zangerl AR, Barenbaum MR, DeLucia EH (2005). Elevated $\mathrm{CO}_{2}$ reduces leaf damage by insect herbivores in a forest community. New Phytologist 167: 207218.

Jones TH, Thompson LJ, Lawton JH, Bezemer $\mathrm{TM}$, Bardgett RD, Blackburn TM, Bruce KD, Cannon PF, Hall GS, Hartley SE, Howson G, Jones CG, Kampichler C, Kandeler E, Ritchie DA (1998). Impacts of rising atmospheric carbon dioxide on model terrestrial ecosystems. Science 280: 441-443.

Kerslake JE, Kruuk LEB, Hartley SE, Woodin SJ (1996). Winter moth Operophtera brumata (Lepidoptera: Geometridae) outbreaks on Scottish heather moorlands: effects of host plant and parasitoids on larval survival and development. Bulletin of Entomological Research 86: 155-164. Lindroth RL, Kinney KK, Platz CL (1993). Responses of deciduous trees to elevated atmospheric $\mathrm{CO}_{2}$ : productivity, phytochemistry and insect performance. Ecology 74: 763-777.

Litvak ME, Constable JVH, Monson RK (2002). Supply and demand processes as controls over needle monoterpene synthesis and concentration in Douglas fir [Pseudotsuga menziesii (Mirb.) Franco]. Oecologia 132: 382-391.

Luterbacher J, Dietrich D, Xoplaki E, Grosjean M, Wanner H (2004). European seasonal and annual temperature variability, trends, and extremes since 1500. Science 303: 1499-1503.

Marchisio C, Cescatti A, Battisti A (1994). Climate, soils and Cephalcia arvensis outbreaks on Picea abies in the Italian Alps. Forest Ecology and Management 68: 375-384.

Parmesan C (2006). Ecological and evolutionary responses to recent climate change. Annual Review of Ecology, Evolution and Systematic 37: 637-639.

Parmesan C, Yohe G (2003). A globally coherent fingerprint of climate change impacts across natural systems. Nature 421: 37-42.

Percy KE, Awmack CS, Lindroth RL, Kubiske ME, Kopper BJ, Isebrands JG, Pregitzer KS, Hendrey GR, Dickson RE, Zak DR, Oksanenq E, Sober J, Harrington R, Karnosky DF (2002). Altered performance of forest pests under atmospheres enriched by $\mathrm{CO}_{2}$ and $\mathrm{O}_{3}$. Nature 420 : 403-407.

Robinet C, Baier P, Pennerstorfer J, Schopf A, Roques A (2007). Modelling the effects of climate change on the potential feeding activity of Thaumetopoea pityocampa (Den. \& Schiff.) (Lep., Notodontidae) in France. Global Ecology and Biogeography [doi: 10.1111/j.1466-8238.2006.00302.x].

Root TL, Price JT, Hall KR, Schneider SH, Rosenzweig C, Pounds JA (2003). Fingerprints of global warming on wild animals and plants. Nature 421: 57-60.

Rosenzweig C, Casassa G, Karoly DJ, Imeson A, Liu C, Menzel A, Rawlins A, Root TL, Seguin B, Tryjanowski P (2007). Assessment of observed changes and responses in natural and managed systems. In: Climate Change 2007: Impacts, Adaptation and Vulnerability. Contribution of Working Group II to the Fourth Assessment Report of the Intergovernmental Panel on Climate Change (Parry ML, Canziani OF, Palutikof JP, van der Linden PJ, Hanson CE eds). Cambridge University Press, Cambridge, UK, pp. 79-131.

Roth SK, Lindroth RL (1994). Effects of $\mathrm{CO}_{2}$-mediated changes in paper birch and white pine chemistry on gypsy moth performance. Oecologia 98: 133-138.

Roth SK, Lindroth RL (1995). Elevated atmospheric $\mathrm{CO}_{2}$ effects on phytochemistry, insect performance and insect parasitoid interactions. Global Change Biology 1: 173-82.

Salvato P, Battisti A, Concato S, Masutti L, Patarnello T, Zane L (2002). Genetic differentiation in the winter pine processionary moth (Thaumetopoea pityocampa - wilkinsoni complex), inferred by AFLP and mitochondrial DNA markers. Molecular Ecology 11: 2435-2444.

Sinclair BJ, Vernon P, Klok CJ, Chown SL (2003). Insects at low temperatures: an ecological perspective. Trends in Ecology and Evolution 18: $257-262$

Smith PHD, Jones TH (1998). Effects of elevated $\mathrm{CO}_{2}$ on the chrysanthemum leafminer, Chromatomyia syngenesiae: a green-house study. Global Change Biology 4: 287-291.

Solomon S, Qin D, Manning M, Alley RB, Berntsen T, Bindoff NL, Chen Z, Chidthaisong A, Gregory JM, Hegerl GC, Heimann M, Hewitson B, Hoskins BJ, Joos F, Jouzel J, Kattsov V, Lohmann U, Matsuno T, Molina M, Nicholls N, Overpeck J, Raga R, Ramaswamy V, Ren J, RusticucciM, Somerville R, Stocker TF, Whetton P, Wood, Wratt D (2007). Technical Summary. In: Climate Change 2007: The Physical Science Basis. Contribution of Working Group I to the Fourth Assessment Report of the Intergovernmental Panel on Climate Change (Solomon S, Qin D, Manning M, Chen Z, Marquis M, Averyt KB, Tignor M, Miller HL eds). Cambridge University Press, Cambridge, United Kingdom and New York, NY, USA.

Speight MR, Hunter MD, Watt AD (1999). Ecology of insects: concepts and applications. Blackwell Science, Oxford, UK.

Stastny M, Battisti A, Petrucco Toffolo E, Schlyter F, Larsson S (2006). Host plant use in the range expansion of the pine processionary moth, Thaumetopoea pityocampa. Ecological Entomology31: 481-490.

Stiling P, Rossi AM, Hungate B, Dijkstra P, Hinkle CR, Knott WM, Drake B (1999). Decreased leaf-miner abundance in elevated $\mathrm{CO}_{2}$ : reduced leaf quality and increased parasitoid attack. Ecological Applications 9: 240-244.

Turchin P, Simon N, Wood SP, Kendall BE, Murdoch WW, Fischlin A, Casas J, Mccauley E, Briggs CJ (2003). Dynamical effects of plant quality and parasitism on population cycles of larch budmoth. Ecology 84: 1207-1214.

Walther G-R, Post E, Convey P, Menzel A, Parmesan C, Beebee TJC, Fromentin J-M, Hoegh-Guldberg O, Bairlein F (2002). Ecological responses to recent climate change. Nature 416: 389-395.

Wilf P, Labandeira CC (1999). Response of plantinsect associations to Paleocene-Eocene warming. Science 284: 2153-2156.

Williams DW, Liebhold AM (1995). Herbivorous insects and global change - potential changes in the spatial-distribution of forest defoliator outbreaks. Journal of Biogeography 22: 665-671.

Williams RS, Lincoln DE, Thomas RB (1994). Loblolly pine grown under elevated $\mathrm{CO}_{2}$ affects early instar pine sawfly performance. Oecologia 98: 64-71.

Zovi D, Stastny M, Battisti A, Larsson S (2008). Ecological costs on local adaptation of an insect herbivore imposed by host plants and natural enemies. Ecology (in press). 